\title{
The influence of reclaimed asphalt pavement in warm mix asphalt on asphalt concrete binder course with Retona Blend 55
}

\author{
Raudhah, R. Jachrizal Sumabrata , Sigit Pranowo Hadiwardoyo \\ University of Indonesia, Civil Engineering Department, 16424 Depok, Indonesia
}

\begin{abstract}
Reclaimed asphalt pavement (RAP) comprises removed pavement materials containing highquality aggregates and asphalt which can be recycled as materials for new pavement construction. It is removed continually for reconstruction, resurfacing, and maintenance purposes, and if not recycled will become waste. This paper determines the influence of using different RAP percentages and asphalt content in warm mix asphalt on the Marshall test results for asphalt concrete binder course (AC-BC) using Retona Blend 55. The percentages of RAP are determined by analyzing the gradation of the existing aggregates in RAP and adding virgin aggregates so that it meets the standard gradation for AC-BC specified by the Ministry of Public Works and Housing. The RAP percentages in the asphalt mixes in this study are 35\%, $45 \%$, and $51.55 \%$ of total aggregates, while the asphalt contents are $5 \%, 6 \%$, and $7 \%$ of the total mix. To determine the influence of RAP percentage and asphalt content, and to discover if there is any influence from the interaction between these two factors, the analysis is performed using a factorial design. The results of this study show that variation in RAP percentages in the mix has no significant influence on stability, flow, and Marshall quotient, but there is significant influence on void in mineral aggregates (VMA), void in mix (VIM), and void filled with asphalt (VFA). Correlations of $97.5 \%, 80 \%$, and 95.1\%, respectively show that increase in RAP percentage increases VMA and VIM and decreases VFA. The interaction between RAP percentage and asphalt content has no significant influence on Marshall test results.
\end{abstract}

\section{Introduction}

Flexible pavement is the most widely used type of pavement. In 2016, the length of paved roads in Indonesia was $287,926 \mathrm{~km}$ and the length of such roads in the country is increasing yearly [1]. The frequent use of flexible pavement causes demand for aggregates and asphalt. Both materials are non-renewable, so the use of virgin materials will continuously diminish the supply of these two resources. Alternative sources such as recycled asphalt are therefore needed to reduce the use of new materials [2].

Asphalt mixing in Indonesia is still often done at hot temperatures, known as 'hot mix asphalt' (HMA). In this study asphalt mixing was carried out at warm temperatures, known as 'warm mix asphalt' (WMA), a method that is more environmentally friendly [3].

\section{Literature Review}

\subsection{Reclaimed asphalt pavement (RAP)}

RAP is a layer of asphalt that is peeled from the pavement for road repairs or to access utilities under the road surface. RAP contains asphalt and aggregates which can be reused in new road construction [2]. RAP has been widely used as a material for the manufacture of flexible pavements in America and Europe, and more than 99\% of asphalt is recycled in America [4]. The use of RAP not only reduces the use of new materials and prevents pollution from asphalt disposal but also reduces construction costs $[2,4]$.

\subsection{Warm mix asphalt (WMA)}

WMA is a technology that allows mixing and processing of asphalt mixtures at temperatures of up to $20-30{ }^{\circ} \mathrm{C}$, i.e. much lower than for HMA [5]. For a lower mixing temperature, less fuel is used, thus reducing the greenhouse gas emissions produced in asphalt mixture production. WMA method with a mixing temperature of $36.5^{\circ} \mathrm{C}$ (i.e. lower than for HMA), resulted in emissions of $\mathrm{SO}_{2}$ decreased by $83 \%, \mathrm{NO}_{\mathrm{X}}$ by $31 \%, \mathrm{CO}$ by $62 \%$, and VOCs by $63 \%[6]$.

In addition to fuel savings and emissions reduction, WMA has other benefits, such as ease of working (because of lower temperatures) that increases worker productivity. Lower temperatures also allow longer processing time. Moreover, WMA uses the same mixing and compaction equipment as HMA, so WMA technology is very easy to implement $[2,3,4]$.

The lower mixing temperature is obtained by additives to the asphalt mixture. These additives reduce the viscosity of asphalt or increase its volume, enabling the asphalt to effectively envelop the aggregate at lower 
temperatures [7]. In this study, the additives used were zeolites, which are non-metallic minerals formed from volcanic sedimentation and found in Indonesia [8]. These minerals are hydrated porous alumina silicate crystals with a three-dimensional skeleton structure formed from tetrahedral $\left[\mathrm{SiO}_{4}\right]$ 4- and $\left[\mathrm{AlO}_{4}\right]$ 5-. Zeolite decreases the viscosity of asphalt by creating a foam effect [9].

\section{Materials and Research Methods}

This research is a quantitative study with an experimental method. The data used in this study were obtained from laboratory test results. This study aims to find out the influence of RAP percentage and asphalt content in the mixture on the Marshall test results for the WMA-RAP in the AC-BC layer. In order to determine the influence of these two factors the experiment is done using factorial design [10]. And to determine the significance of the influence, two-way analysis of variance (ANOVA) is performed using SPSS [11].

The main material used in the asphalt mixture was RAP. This material had been peeled from the existing road and was taken to the laboratory for extraction and tested for asphalt content and aggregate gradation. Once both were known, could determine how much virgin asphalt and virgin aggregates that need to be added to the mixture. The asphalt used in this study is Retona Blend 55. It is a blend of petroleum asphalt and natural rock asphalt from Buton island, Indonesia [12].

The variation in RAP aggregates percentage were $51.55 \%, 45 \%$, and $35 \%$ of total aggregates, and the variation in asphalt content were $5 \%, 6 \%$, and $7 \%$. For each group 3 specimens were made. Therefore there were 27 specimens in total. Then Marshall tests were carried out to determine stability, flow, Marshall quotient, void in mineral aggregates, void in mix and void filled with asphalt.

\section{Results and Analysis}

\subsection{Reclaimed asphalt pavement}

In this study, 12 extractions were carried out and it was found that the RAP consisted of $5.807 \%$ asphalt and 94.193\% aggregates. RAP asphalt characteristics can be seen in Table 1. After a long-term aging, asphalt becomes hard and less workable [13]. It is indicated by low penetration, low ductibility and high softening point.

Table 1. RAP asphalt.

\begin{tabular}{|l|c|c|}
\hline \multicolumn{1}{|c|}{ Test } & Test methods & Results \\
\hline Penetration at $25^{0} \mathrm{C}(0.1 \mathrm{~mm})$ & SNI 2456-2011 & 8.73 \\
\hline Softening point $\left({ }^{0} \mathrm{C}\right)$ & SNI 2434-2011 & 72 \\
\hline Ductility at $25^{0} \mathrm{C}(\mathrm{mm})$ & SNI 2432-2011 & 42 \\
\hline Flash point $\left({ }^{0} \mathrm{C}\right)$ & SNI 2433-2011 & 240 \\
\hline Specific gravity & SNI 2441-2011 & 1.061 \\
\hline
\end{tabular}

4.2 Marshall test results

\subsubsection{Stability}

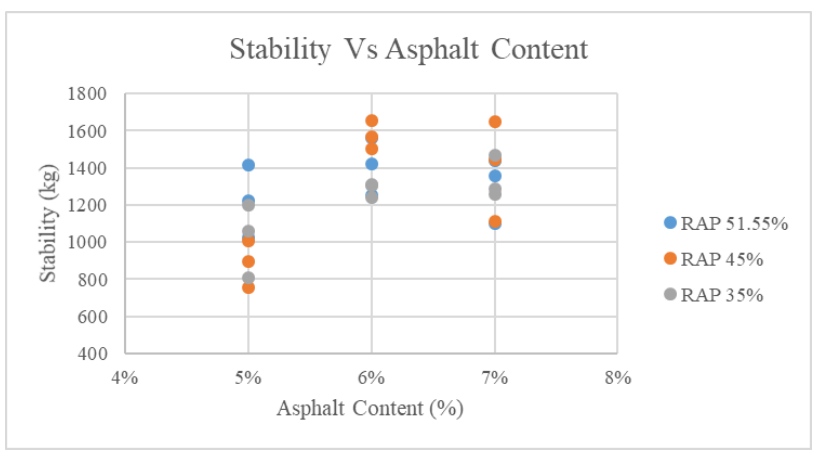

Fig. 1. Stability vs. asphalt content.

Stability is the maximum load that can be held by the asphalt mixture. Figure 1 shows the relationship between stability and asphalt content in the asphalt mixture for each mixture with RAP aggregate percentage of $51.55 \%$, $45 \%$, and $35 \%$. From the graph it can be seen that in the samples with RAP of $51.55 \%$ and $45 \%$ the highest stability value obtained was from the sample with $6 \%$ asphalt content. Whereas in the sample with $35 \%$ RAP aggregate, the highest stability value was obtained from samples with $7 \%$ asphalt content. This could be due to the asphalt mixture with $35 \%$ RAP aggregate containing more virgin aggregate. RAP aggregates have been mixed with asphalt while new aggregates have not been mixed with asphalt. With more virgin aggregates, more aggregate surfaces have not been covered with asphalt so more virgin asphalt is needed. Therefore the 7\% asphalt mixture in samples with $35 \%$ RAP aggregates has a higher stability than samples with $5 \%$ and $6 \%$ asphalt content.

\begin{tabular}{|c|c|c|c|c|c|}
\hline \multicolumn{6}{|c|}{ Tests of Between-Subjects Effects } \\
\hline Dependent Variable: Stabill & & & & & \\
\hline & $\begin{array}{l}\text { Type III Sum of } \\
\text { Squares }\end{array}$ & df & Mean Square & $\mathrm{F}$ & Sig. \\
\hline Corrected Model & $1041174.660^{\mathrm{a}}$ & 8 & 130146.833 & 4.823 & 003 \\
\hline Intercept & 43676868.170 & 1 & 43676868.170 & 1618.559 & .000 \\
\hline RAP Percentage & 43709.683 & 2 & 21854.841 & 810 & .460 \\
\hline Asphalt Content & 732817.223 & 2 & 366408.612 & 13.578 & .000 \\
\hline $\begin{array}{l}\text { RAP Percentage * Asphalt } \\
\text { Content }\end{array}$ & 264647.754 & 4 & 66161.939 & 2.452 & 083 \\
\hline Error & 485730.462 & 18 & 26985.026 & & \\
\hline Total & 45203773.290 & 27 & & & \\
\hline Corrected Total & 1526905.122 & 26 & & & \\
\hline
\end{tabular}

Fig. 2. ANOVA factorial design test results using SPSS (stability).

Figure 2 shows that the significance of the influence of RAP percentage is 0.46 . This figure is greater than 0.05 , so the influence of RAP percentages on the stability of asphalt mixtures is not significant. The significance of the influence of asphalt content was 0 . This means that $100 \%$ asphalt content affects the stability of the asphalt mixture. While the significance of the interaction influence of the two factors is 0.083 . This means that the interaction influence of the two factors on the stability of asphalt mixture is not significant. 


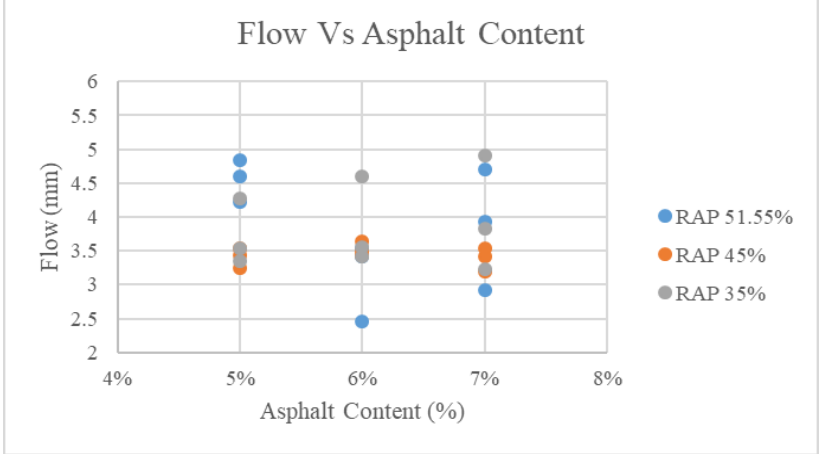

Fig. 3. Flow vs. asphalt content.

Flow is the amount of deformation that occurs in the asphalt mixture when it collapses. Figure 3 shows the relationship between flow and asphalt content for each mixture with RAP aggregate of $51.55 \%, 45 \%$, and $35 \%$. In the sample with $45 \%$ and $35 \%$ RAP, asphalt content does not strongly affect flow. In samples with RAP aggregate content of $51.55 \%$, the highest flow was obtained from samples with $6 \%$ asphalt content.

\begin{tabular}{|c|c|c|c|c|c|}
\hline \multirow{3}{*}{$\begin{array}{l}\text { Dependent Variable: Flow } \\
\text { Source }\end{array}$} & \multicolumn{5}{|c|}{ Tests of Between-Subjects Effects } \\
\hline & & & & & \\
\hline & $\begin{array}{c}\text { Type III Sum of } \\
\text { Squares }\end{array}$ & df & Mean Square & $\mathrm{F}$ & Sig. \\
\hline Corrected Model & $4.189^{a}$ & 8 & .524 & 1.755 & 153 \\
\hline Intercept & 372.076 & 1 & 372.076 & 1247.446 & .000 \\
\hline RAP Percentage & 1.025 & 2 & .513 & 1.719 & 207 \\
\hline Asphalt Content & 690 & 2 & .345 & 1.157 & .337 \\
\hline $\begin{array}{l}\text { RAP Percentage * Asphalt } \\
\text { Content }\end{array}$ & 2.473 & 4 & .618 & 2.073 & 127 \\
\hline Error & 5.369 & 18 & 298 & & \\
\hline Total & 381.633 & 27 & & & \\
\hline Corrected Total & 9.557 & 26 & & & \\
\hline
\end{tabular}

Fig. 4. ANOVA factorial design test results using SPSS (flow).

From the ANOVA test in Figure 4, the significance of the influence of RAP percentage, asphalt content, and the interaction of RAP and asphalt content were 0.207, 0.337, and 0.127 , respectively. All three are greater than 0.05 , which means that these influences on the flow of the asphalt mixture are not significant.

\subsubsection{Marshall quotient}

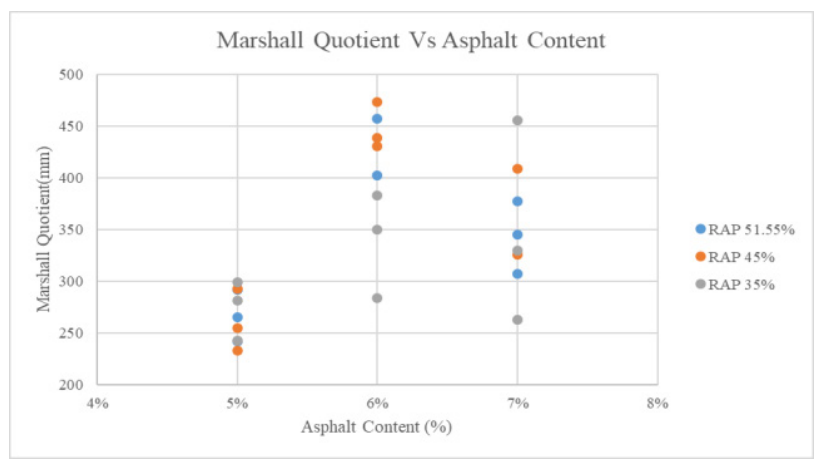

Fig. 5. Marshall quotient vs. asphalt content.

Figure 5 shows the relationship between Marshall quotient (MQ) and asphalt content for mixtures with RAP of $51.55 \%, 45 \%$, and $35 \%$. From the graph, it can be seen that in the samples with $51.55 \%$ and $45 \%$ RAP, the highest MQ occurred in samples with $6 \%$ asphalt content. This is because in the sample with $51.55 \%$ and $45 \%$ RAP aggregate the highest stability occurred in samples with $6 \%$ asphalt content, while the flow was not much different in the $5 \%, 6 \%$, and $7 \%$ samples. In the sample with $35 \%$ RAP aggregate, the highest stability occurred in samples with $7 \%$ asphalt content and there was no difference in the flow of samples with asphalt content of $5 \%, 6 \%$, and $7 \%$.

\begin{tabular}{|c|c|c|c|c|c|}
\hline & ts of Bet & i-Subje & cts Effects & & \\
\hline Dependent Variable: Mars| & IIQQuotient & & & & \\
\hline & $\begin{array}{c}\text { Type III Sum of } \\
\text { Squares }\end{array}$ & df & Mean Square & $\mathrm{F}$ & Sig. \\
\hline Corrected Model & $139154.590^{\mathrm{a}}$ & 8 & 17394.324 & 5.543 & .001 \\
\hline Intercept & 3314798.021 & 1 & 3314798.021 & 1056.324 & .000 \\
\hline RAP Percentage & 13455.071 & 2 & 6727.535 & 2.144 & .146 \\
\hline Asphalt Content & 103080.313 & 2 & 51540.157 & 16.424 & .000 \\
\hline $\begin{array}{l}\text { RAP Percentage * Asphalt } \\
\text { Content }\end{array}$ & 22619.206 & 4 & 5654.802 & 1.802 & .172 \\
\hline Error & 56484.928 & 18 & 3138.052 & & \\
\hline Total & 3510437.539 & 27 & & & \\
\hline Corrected Total & 195639.518 & 26 & & & \\
\hline
\end{tabular}

Fig. 6. ANOVA factorial design test results using SPSS (Marshall quotient).

Figure 6 shows that the significance of the influence of RAP percentage and the interaction influence of RAP percentages and asphalt content are 0.146 and 0.172 . This means that these two factors have no significant influence on the Marshall asphalt mixture quotient, while the significance of the influence of asphalt content is 0 . This means that the influence of asphalt content is very significant for the Marshall quotient.

\subsubsection{Void in mineral aggregates (VMA)}

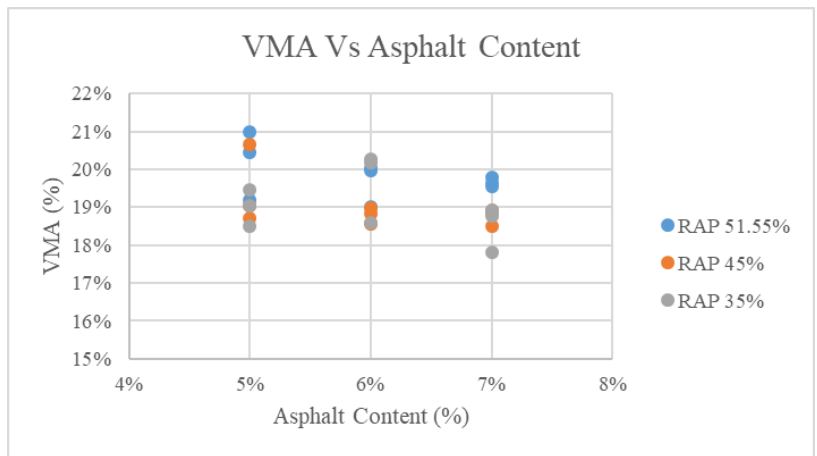

Fig. 7. VMA vs. asphalt content.

VMA is the volume of cavity between the aggregate particles to the total volume. From Figure 7 it can be seen in the samples with RAP aggregate of $51.55 \%$ and $45 \%$ the greater the asphalt content the smaller the VMA value. In samples with asphalt content of $5 \%$ and $7 \%$, the greater the percentage of aggregate RAP in the mixture, the greater the VMA value. This is because the greater the percentage of RAP aggregate, the greater the RAP asphalt content of the total asphalt used in the mixture. RAP asphalt is hard and brittle and has lower workability. With more workability, the mixture is more easily 
blended therefore more aggregate surface is covered with asphalt.

\begin{tabular}{l|r|r|r|r|r} 
Dependent Variable: VMA & $\begin{array}{l}\text { Tests of Between-Subjects Effects } \\
\text { Type III Sum of } \\
\text { Squares }\end{array}$ & df & Mean Square & \multicolumn{1}{c}{ F } & Sig. \\
\hline Source & $7.613^{\mathrm{a}}$ & 8 & .952 & 2.212 & .077 \\
\hline Corrected Model & 10059.350 & 1 & 10059.350 & 23377.510 & .000 \\
\hline Intercept & 3.932 & 2 & 1.966 & 4.569 & .025 \\
\hline RAP Percentage & 1.648 & 2 & .824 & 1.915 & .176 \\
\hline Asphalt Content & 2.033 & 4 & .508 & 1.181 & .352 \\
\hline $\begin{array}{l}\text { RAP Percentage * Asphalt } \\
\text { Content }\end{array}$ & 7.745 & 18 & .430 & & \\
\hline Error & 10074.708 & 27 & & & \\
\hline Total & 15.359 & 26 & & & \\
\hline Corrected Total & & & & & \\
\hline
\end{tabular}

Fig. 8. ANOVA factorial design test results using SPSS (VMA).

From the results of the ANOVA test for VMA shown in Figure 8, the significance of the influence of RAP percentages, asphalt content, and the interaction of RAP percentages and asphalt content are $0.025,0.176$, and 0.352. This means that the influence of asphalt content and the interaction of both have no influence on asphalt VMA. However, RAP percentages have a significant influence on VMA with a correlation of $97.5 \%$.

\subsubsection{Void in mix (VIM)}

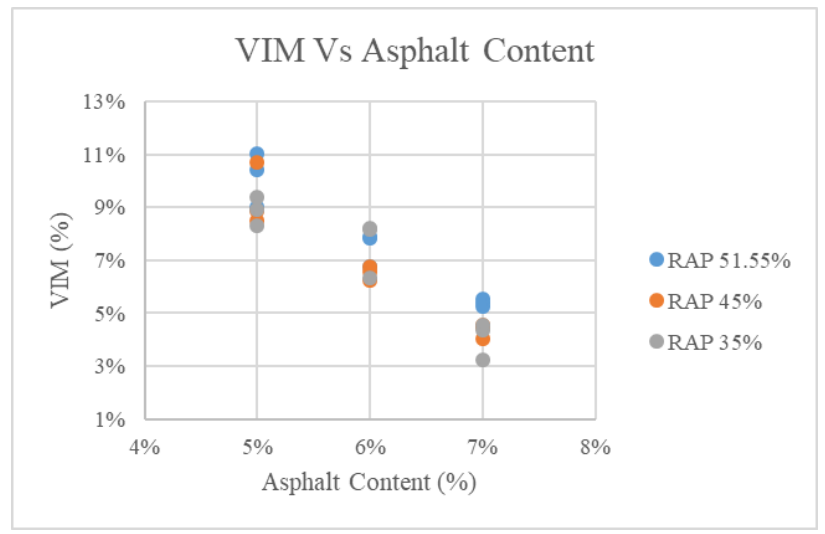

Fig. 9. VIM vs. asphalt content.

VIM is the total volume of air between asphalt-coated aggregate particles. From Figure 9 it can be seen that for the three percentages of RAP aggregate, the value of VIM decreases with increasing levels of asphalt in the mixture. This is because the more asphalt used, the more cavities are filled with asphalt so the total air in the mixture decreases. In samples with asphalt content of 5\% and $7 \%$, samples with a higher percentage of RAP aggregate had a higher VIM. This is because the nature of the RAP asphalt is hard, so it is less able to cover the aggregate surface and so fewer cavities are filled with asphalt. Therefore, the higher the content of RAP asphalt in the mixture, the greater the air volume in the mixture.

\begin{tabular}{|c|c|c|c|c|c|}
\hline \multirow{3}{*}{$\begin{array}{l}\text { Dependent Variable: VIM } \\
\text { Source }\end{array}$} & \multicolumn{5}{|c|}{ Tests of Between-Subjects Effects } \\
\hline & & & & & \\
\hline & $\begin{array}{c}\text { Type III Sum of } \\
\text { Squares }\end{array}$ & df & Mean Square & $\mathrm{F}$ & Sig. \\
\hline Corrected Model & $374.004^{a}$ & 8 & 46.751 & 4.309 & .005 \\
\hline Intercept & 1908.900 & 1 & 1908.900 & 175.943 & .000 \\
\hline RAP Percentage & 106.062 & 2 & 53.031 & 4.888 & .020 \\
\hline Asphalt Content & 159.323 & 2 & 79.661 & 7.342 & .005 \\
\hline $\begin{array}{l}\text { RAP Percentage * Asphalt } \\
\text { Content }\end{array}$ & 108.620 & 4 & 27.155 & 2.503 & .079 \\
\hline Error & 195.291 & 18 & 10.850 & & \\
\hline Total & 2478.196 & 27 & & & \\
\hline Corrected Total & 569.296 & 26 & & & \\
\hline
\end{tabular}

Fig. 10. ANOVA factorial design test results using SPSS (VIM).

Figure 10 shows the significance of the influence of RAP percentages and asphalt content and the interaction of both are $0.02,0.005$, and 0.079 . From these results it is evident that percentage of RAP and asphalt content have a significant influence on VIM, with a correlation of $80 \%$ and $99.5 \%$ respectively. The interaction of RAP percentages and asphalt content, however, does not have a significant influence on VIM.

\subsubsection{Void filled with asphalt (VFA)}

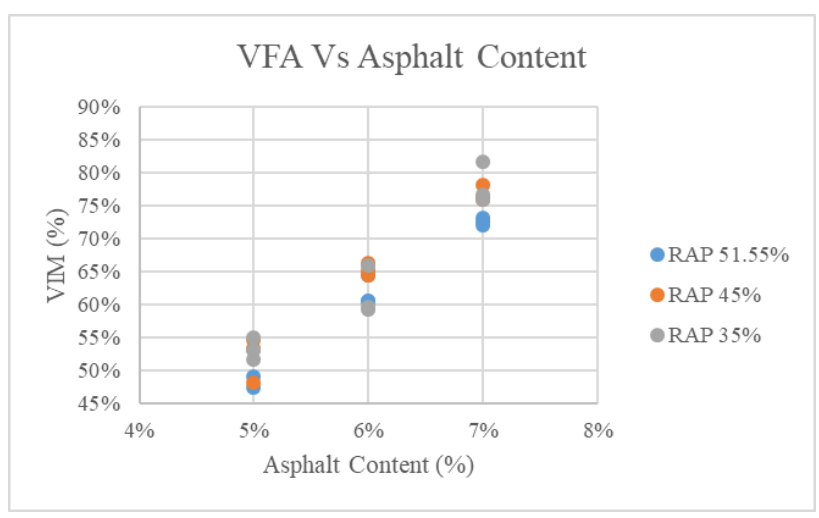

Fig. 11. VFA vs. asphalt content.

Figure 11 shows that for the three percentages of RAP aggregate, the greater the asphalt content in the mixture, the greater the VFA. This is because the more asphalt used, the more cavities in the mixture are filled with asphalt. Therefore, VFA is inversely proportional to VIM. For samples with asphalt content of $5 \%$ and $7 \%$, the greater the aggregate percentage of RAP, the smaller the VFA value. The greater the percentage of RAP aggregate in the mixture, the greater the RAP asphalt content is than the total asphalt so that the asphalt becomes harder. Therefore, with the same asphalt content, asphalt mixtures with higher levels of RAP asphalt are less able to cover the aggregate surface, causing less cavities to be filled with asphalt. 


\begin{tabular}{l|r|r|r|r|r|} 
Dependent Variable: VFA & $\begin{array}{c}\text { Tests of Between-Subjects Effects } \\
\text { Type III Sum of } \\
\text { Squares }\end{array}$ & df & Mean Square & \multicolumn{1}{c|}{ F } & Sig. \\
\hline Source & 2714.387 a & 8 & 339.298 & 56.068 & .000 \\
\hline Corrected Model & 108924.144 & 1 & 108924.144 & 17999.388 & .000 \\
\hline Intercept & 58.417 & 2 & 29.209 & 4.827 & .021 \\
\hline RAP Percentage & 2620.156 & 2 & 1310.078 & 216.486 & .000 \\
\hline Asphalt Content & 35.814 & 4 & 8.953 & 1.480 & .250 \\
\hline $\begin{array}{l}\text { RAP Percentage"Asphalt } \\
\text { Content }\end{array}$ & 108.928 & 18 & 6.052 & & \\
\hline Error & 111747.459 & 27 & & & \\
\hline Total & 2823.315 & 26 & & & \\
\hline Corrected Total & & & & & \\
\hline
\end{tabular}

Fig. 12. ANOVA factorial design test results using SPSS (VFA).

The results of the ANOVA test in Figure 12 show the significance of the influence of RAP percentage and asphalt content, and the interaction of the two factors is $0.021,0.000$, and 0.25 . This means that the percentage of RAP and asphalt content have a significant influence on VFA with a correlation of $97.9 \%$ and $100 \%$, respectively. The interaction of the two factors, however, does not have a significant influence on the VFA.

\section{Conclusion}

- $\quad$ RAP used in this study consists of $5.807 \%$ asphalt and $94.193 \%$ aggregate.

- The results of the RAP asphalt characteristics test are penetration of 8.7 , softening point of $72{ }^{\circ} \mathrm{C}$, and ductility of $42 \mathrm{~mm}$. RAP asphalt is brittle and hard causing it to have very low workability. In future experiments asphalt rejuvenation should be performed or more virgin asphalt should be added to the mixture to increase workability. Therefore producing asphalt mixture with better characteristics.

- $\quad$ The RAP aggregate percentage in the mixture has a significant influence on VMA, VIM, and VFA.

- Asphalt content in the mixture has a significant influence on stability, Marshall quotient, VIM, and VFA.

- The interaction of RAP percentages and asphalt content did not have a significant influence on the Marshall test results.

\section{Acknowledgment}

Authors are grateful to the DPRM University of Indonesia for the financial support through PITTA 2018 grant. The experimental work was completed in the Material and Structure Laboratory University of Indonesia

\section{References}

1. Badan Statistik Indonesia [Statistics Indonesia]. (1957-2016). Panjang jalan menurut jenis permukaan [Road length based on surface type]. Retrieved from

http://www.bps.go.id/linkTableDinamis/view/id/820.
2. Federal Highway Administration. (2011). Reclaimed asphalt pavement in asphalt mixtures: state of the practice. Retrieved from http://www.fhwa.dot.gov/publications/research/infras tructure/pavements/11021/11021.pdf

3. H.A. Rondón-Quintana, J.A. Hernández-Noguera, and F.A. Reyes-Lizcano, Ingeniería e Investigación vol. $35 \quad n .^{\circ} 3$, december - 2015 (5-18). DOI:http://dx.doi.org/10.15446/ing.investig.v35n3.5 0463

4. National Asphalt Pavement Association. (2015). $6^{\text {th }}$ annual survey: recycled materials and warm-wix asphalt usage 2015.

5. N. Wahjuningsih, R.J. Sumabrata, S.P. Hadiwardoyo, E3S Web of Conferences 34, 01032 (2018)

6. Ohio Research Institute for Transportation and the Environment. (2009). Performance assessment of marm mix asphalt (WMA) pavements. Retrieved from

https://rosap.ntl.bts.gov/view/dot/16978/dot_16978_ DS1.pdf?

7. M. Zaumanis, V. Haritonovs,. (2010). Research on properties of warm mix asphalt, Scientific Journal of Riga Technical University, Construction Science, Vol 11, 77-84.

8. Kusdarto. (2008). Potensi zeolit di Indonesia [Zeolit potential in Indonesia]. Jurnal Zeolit Indonesia, 7(2), 78-87.

9. A. Woszuk, W. Franus, A review of the application of zeolite materials in warm mix asphalt technologies (2017)

10. N. Lathifah, Analisis pengaruh penambahan BNA-R pada aspal dengan metode faktorial desain [Analysis of influence of BNA-R addition in asphalt using factorial experimental design method]. (Undergraduate thesis, 2017). Unpublished.

11. A. Field, Discovering statistics using SPSS. $3^{\text {rd }}$ edition. (2009)

12. Sumarji, Penggunaan aspal Buton tipe retona blend 55 sebagai bahan susun campuran HRS-B [The use of Buton asphalt type retona blend 55 as a component of HRS-B mix]. Jurnal Teknik, 2(1), 1824

13. L.X. Dai, Evaluation of warm mix asphalt performance incorporating high reclaimed asphalt pavement content (ME Thesis, University of Canterbury, 2016) 